\title{
INTERDISCIPLINARY APPROACH IN THE STUDY OF MARITAL LAW (STUDY OF THE DETERMINATION OF CHILD COSTODY)
}

\author{
Silfa Afriyani ${ }^{1}$
}

\begin{abstract}
An interdisciplinary approach is an approach that uses various scientific fields in solving a problem. The determination of child custody is usually decided by considering the age of the child. Children who are not yet mumayiz are taken care of by the mother, but when the child is an adult, they are given the choice to live with the mother or father. Through this study, the author examines the determination of child custody according to Islamic law and the Marriage Law and by using psychology and economics. That the custody of children in care must be assigned to the right person. From this paper, the author concludes that according to Islamic law, the determination of child custody takes into account the age of the child. According to Law no. 1 of 1974 concerning Marriage, the determination of child custody before adulthood is decided by a local court judge. In psychology, the determination of child custody takes into account the mental or psychological aspects of the child. Especially in terms of the child's emotional closeness, closer to the mother or father. So that way, the child's condition will be better in living their daily lives and not getting pressure. Meanwhile, by using economics, the determination of child custody is seen from the financial stability of both parents, both from the mother and from the father. Because in carrying out child care requires financially established, so that the needs of children can be met properly. So, in determining child custody, it can not only be seen from the age of the child but can use other considerations.
\end{abstract}

Keywords: Child custody, Mother, Father

\section{The Introduction}

The struggle for child custody between husband and wife has also become a familiar topic for the community. Many child custody issues have been resolved in court. Children are the responsibility of both parents who must be cared for and cared for with love and affection. The determination of child custody will be decided by a court judge. Children who are still underage have more dominant parenting rights to their mothers. However, not a few children who are still under the age of custody are assigned to their fathers because there are several considerations.

Child custody has been regulated in Law Number 1 of 1974 concerning Marriage and the Compilation of Islamic Law (KHI). The stipulation of child custody according to these two regulations is mutually reinforcing. The determination of child custody can also use an interdisciplinary approach. An Interdisciplinary approach is an approach that uses a review from various scientific perspectives that are coherent and relevant in solving a problem. In this paper, the author wants to use an interdisciplinary approach in determining child custody in terms of Islamic law, Marriage Law, psychological and economic. In determining the holder of child custody $1 \quad \begin{aligned} & \text { Universitas Islam Negeri } \\ & \text { silfa.afriyani98@gmail.com }\end{aligned}$ Sunan Kalijaga Yogyakarta, Email 
several things must be considered, not only focusing on the age of the child. Because the future survival of the child depends on who gets custody.

In this paper, the author tries to develop by including the writings that have been studied and made by previous researchers related to this discussion. The writings are grouped into two. The first group is articles that discuss interdisciplinary approaches in family law. The writings in this group include the writings of Khoiruddin Nasution "Rational-Scientific Thinking and International and Multidisciplinary Approaches in the Study of Islamic Family Law", Journal: Al-Ahwal, Vol. 10, No. 1 (June 2017). This paper concluded that students need to get used to thinking, writing, speaking, and acting rationally and scientifically. There must be a good understanding of using the study approach of Islamic Family Law and Syamsul Darlis "Combination of Thematic-Interdisciplinary Methods in Islamic Family Law Reform", Journal: Samarah, Vol. 2, No. 2 (July-December 2018). The conclusion of this paper is an interdisciplinary method combining several scientific disciplines to solve problems. For example, in determining inheritance for men and women, the distribution is based on the condition of the economic welfare of the heirs, namely through deliberation.

While the writings of the second group discuss the interdisciplinary approach in Islamic education. The articles included in this group include Chanifudin "Interdisciplinary Approach: Governance of Islamic Education in the Middle of Complexity", Islamic Education Journal of Islamic Education, Vol. 05 (January 2016). This paper concludes that two factors are using an interdisciplinary approach in curriculum development, namely first, the empirical factor that there are interrelated aspects in life. Second, the scientific theoretical factor that problems in life continue to develop with the development of science and technology, Ni'mawati Uus Ruswandi Mohamad Erihadiana Ni'mawati, Uus Ruswandi, and Mohamad Erihadiana, "Monodisciplinary and Interdisciplinary Research Studies in Islamic Education Facing National and Global Issues: Studies Case Against Covid-19 Issues", Journal: Misykat, Vol. 5, No. 1 (June 2020). This paper concludes that Islamic religious education is closely related to national and global issues regarding the case of the Covid-19 pandemic using several disciplines. Such as Islam, hadith, the science of interpretation, figh, and the science of kalam. Covid is also related to health sciences using an interdisciplinary approach, namely psychology, pharmacology, and health. As well as its impact on the field of political economy and so on, and Hifza Muhammad Suhardi Aslan Silvia Ekasari "Leadership of Islamic Education in an Interdisciplinary Perspective" Journal: NidhomulHaq, Vol. 5, No. 1 (2020). The conclusion of this paper is from a sociological perspective, leadership is the existence of challenges after challenges by following under technological developments, in dealing with them must hold the principle values in Islam. While leadership from a political perspective is a challenge with individuals, institutions, organizations, parties, and other institutions so that they must compete healthily without expecting any outside help.

From the research above written by previous researchers, there are differences in the discussion of the interdisciplinary approach. The author examines the interdisciplinary approach in the study of marriage law which is reviewed from several fields such as Islamic law, Marriage Law, psychology, and in terms of economics. Thus, the existence of this research is 
to add insight for readers from both academics and the wider community that the determination of child custody can be viewed from several fields.

\section{Research Methods}

Types of research

In this type of research, the author uses library research, namely research conducted by collecting information and data with the help of reference books, similar previous research results, articles, notes, and other scientific works (Milya sari, 2020).

\section{Data source}

Sources of research using secondary data, namely data obtained from books, journals, articles, and other writings. Secondary data is data obtained from certain parties used by researchers. In this study, data sources are used from books, journals, articles, and other writings related to the subject matter, namely interdisciplinary and the determination of child custody (Tarjo, 2019).

Data collection technique

The data analysis technique used in this research is descriptive qualitative analysis, which describes, presents, or explains in depth all the problems formulated in the main problem. The qualitative descriptive analysis emphasizes focusing on the data to be taken and then presenting the data in the form of brief descriptions, charts, and relationships between categories (Yuliani, 2018).

In this writing, the author uses library research. Sources of research using secondary data, namely data obtained from books, journals, articles, and other writings. The form of the research is descriptive, which is collected from sources and analyzed in-depth so that it can produce targeted conclusions.

\section{Discussion and Results}

\section{Understanding Interdisciplinary}

The interdisciplinary approach (interdisciplinary approach) is an approach to solving a problem by using a review from various perspectives of cognate and relevant sciences. Relevant science is the knowledge that can be used in solving problems using an approach (Sudikan, 2015).

The sciences used in the interdisciplinary approach are related to each other. The main characteristic of the interdisciplinary approach is inter, a blend of knowledge within the same family. Cognate sciences are sciences that are in a certain science family, for example, such as Natural Sciences (IIK), Social Sciences (IIS), or Cultural Sciences (IIB) (Ni'mawati, 2020).

Some interpret interdisciplinary means to work together between one science so that it is a unit with a method. It can also be said that interdisciplinary is between one science and another, thus forming a new science in solving a problem. The importance of this approach is increasingly recognized by the limitations of the results of many studies that only use one particular approach. For example, in studying the science of religious texts, such as the Qur'an and the Sunnah of the Prophet, it is not enough just to use 
a textual approach but must be equipped with a sociological or historical approach, it can also add a hermeneutic approach (Rohmatika, 2019).

From some of the definitions above, in this paper, the author uses an interdisciplinary approach by using various scientific perspectives in solving a problem. The Knowledge that can be used in finding solutions to problems. In this case, the author uses Islamic law, the Marriage Act, psychology, and economics. From several points of view of this science, the author examines that it can solve the problem of child custody due to divorce.

\section{Understanding Hadanah}

Hadanah according to the language is "putting something near the ribs or in the lap", because the mother when breastfeeding her child put the child in her lap as if the mother was protecting and caring for her child. Hadanah is educating or caring for someone who has not been mumayiz or who has lost his intelligence because they cannot do their own needs (Sarong, 2010).

According to Imam Mazhab, there are several differences of opinion regarding the definition of hadanah, namely:

1. Fuqaha Hanifah defines hadanah as an effort to educate children which will be carried out by someone who has the right to care for them

2. Syafi'iyah scholars, hadanah is educating people who cannot take care of themselves with what is good for themselves and maintain what is harmful to themselves, even though the person is an adult. Such as helping in terms of cleaning his body, washing his clothes (Muhajirin, 2017).

Hadanah is different from education (tarbiyah). Hadanah contains the notion of physical and spiritual maintenance as well as education for children. Educators may consist of the child's family and may also not be from the child's family and it is a professional job, while hadanah is carried out and carried out by the child's family. Hadanah is the right of hadhin, while education is not necessarily the right of hadhin.

The obligation to care for and care for children is the obligation of their parents, namely the mother and father. Parents are obliged to nurture and educate their children so that they become useful children for religion, nation, and state. Parents are also obliged to teach children to fear Allah SWT.

\section{Determination of Child Custody in terms of Islamic Law}

Islamic law has a purpose to protect the benefit of the people. The law that was sent down is not in vain but has a reason that has been supported by God's wisdom. The needs that a child needs in their growth and development are basic secondary needs and tertiary needs (Hifni, 2016).

Custody of children (hadanah) is also explained in the Qur'an and Hadith, namely:

a. Al-Qur'an

As the word of Allah SWT in the letter al-Baqarah verse 233: 


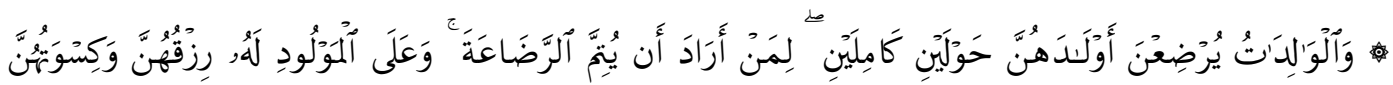

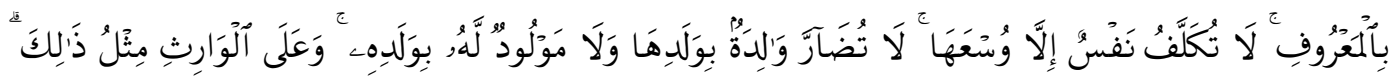

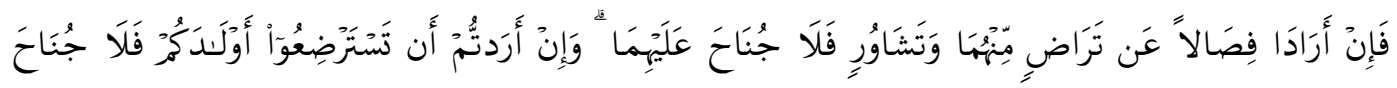

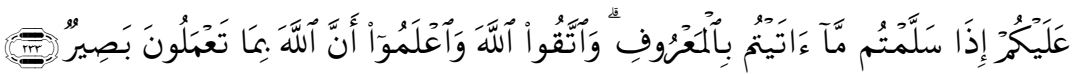

"And mothers should breastfeed their children for two whole years, for those who want to breastfeed completely. And the father must provide for their maintenance and clothing properly. A person is not burdened more than he can bear. A mother should not suffer because of her child and neither should a father suffer because of his child. The heirs are (obligated) like that too. If both want to wean by agreement and deliberation between them, then there is no sin on either of them. And if you want to nurse your child to someone else, then there is no sin for you to pay it properly. Fear Allah and know that Allah is All-Seer of what you do".

The verse above explains about Allah commanding to take care of children by obliging the mother to breastfeed her child for two full years, and the obligation of a father to earn a living for the mother and child in a good way.

as the Prophet SAW said:

"From the hadith narrated from Amr bin Shuaib from his father, from his grandfather Abdullah bin Mar, that a woman said to the Messenger of Allah, "O Messenger of Allah, indeed my son has made my stomach as a shelter, my milk as a drink, and my lap as a shelter, while his father had rejected me seemed to want to take it from me ". Then the Messenger of Allah said: "You are more entitled to it as long as you are not married" (H. R. Ahmad, Abu Dawud).

From the above hadiths, it has been explained that a mother has more rights than her father as long as the mother has not remarried. A mother is prioritized over a father because a mother can care for and breastfeed, can educate, is more patient, and has more time for her mother because that is why mothers have more rights for the good of their children.

Child care aims to help children meet their needs because they have not been able to serve their own needs. Fiqh experts agree that the right to care for children is from the time the baby is born until the age of tamyiz, but fiqh experts have different opinions on when the tamyiz age is. According to the Hanafi school, the right to care for children is until the child can do his own daily needs, the age limit for child care for men is seven years, but according to some others, it is nine years. Meanwhile, the period of parenting for women ends at the age of nine years, and according to some others, it is eleven years. If the daughter has reached adulthood and her sexual power has been seen, then the father is more appropriate to take care of her (Muhajirin, 2017).

According to Imam Syafi'i if a husband divorces his wife and has children from a relationship with his wife, the wife is more entitled to take care of the child until he is 7 years old. Then, the child is given a choice between joining the mother or following the father, and it is handed over to 
whom he chooses. Then the child was handed over to him (Najjeh, 2017). With the evidence of the hadith of the prophet, which means:

"From Abu Hurairah Ra, it is narrated that the Prophet $S A W$ ordered a child to choose between his father and mother." (H. R. At-Tarmizi)

"A woman came to the Messenger of Allah and said, "O Messenger of Allah, my husband wants to take my son away, even though he is very useful for me. He can help me fetch water from Abu Anbah's well." The Messenger of Allah (saw) said, "Vote!" He said, "Who did this?" The Prophet SAW said, "This is your father and your mother, hold the hand of one of them as you wish".

According to Imam Maliki, the period of the upbringing of a boy is until he has wet dreams, in other words, the child has reached puberty. Then he can choose to live in the care of his mother or the care of his father or even support himself. However, regarding education, if the father wants to send him to school, it is okay on the condition that when the business is finished, it must be returned to his mother. A father may not separate a mother from her child unless the mother remarries.

Regarding the upbringing period for girls, Imam Maliki thinks believes that the upbringing period is until she is married and has intercourse with her husband. If the child is not married until the age of 30 or 40 years, then the care period is still with the mother. However, if the child is feared that something undesirable will happen, then the father or guardian must be responsible for the child (Muhajirin, 2017).

It is so important regarding child care, that in the Compilation of Islamic Law (KHI) in article 104 it states:

1. All costs of breastfeeding the child are accounted for by the father. If the father dies, breastfeeding is borne by the person who is obliged to provide for his father or guardian.

2. Breastfeeding is carried out for a maximum of two years, and weaning can be carried out in less than two years with the consent of the father and mother.

Article 105 of the KHI states that in the event of a divorce:

1. It is the right of the mother to take care of a child who is not yet mumayiz or not yet 12 years old.

2. The care of a child who has mumayiz is left to the child to choose between his father and mother as the holder of the right of care.

3. The cost of maintenance is borne by his father.

From this explanation, it is clear that parents do not need to fight over child custody, because the issue in the Compilation of Islamic Law (KHI) has regulated that child custody is given to the mother. However, his father still fulfills all of these needs, so that the child can grow and develop well (Zainuddin, 2020).

\section{Determination of Child Custody in terms of Law Number 1 of 1974 concerning Marriage}

Marriage has the main goal of getting offspring, forming a harmonious household based on love and affection between family members. According to Law Number 1 of 1974 concerning Marriage, Article 2 states that (1) 
Marriage is legal if it is carried out according to the laws of each religion and belief. (2) each marriage is recorded according to the prevailing laws and regulations. From the article, it has been explained that every marriage, apart from being carried out according to religion, must also be registered before a Marriage Registration Officer to have a strong position before the law.

Husband and wife who cannot maintain the integrity of their household choose to divorce. However, not all divorces are caused by conflicts between husband and wife. Divorce can be caused by death, commonly referred to as a death divorce. As a result of the divorce, problems regarding joint property and child custody. Law Number 1 of 1974 concerning marriage in article 41 concerning the obligations of parents in raising children.

Article 41:

1. Both mother and father are still obliged to maintain and educate their children, solely based on the interests of the child, if there is a dispute regarding the children's decision, the Court gives its decision;

2. The father is responsible for all the maintenance and education costs needed by the child, if the father is, in fact, unable to fulfill these obligations, the Court can determine that the mother is also responsible for the costs;

3. The court may require the ex-husband to provide living expenses and/or determine an obligation for the ex-wife.

Regarding the child custody rights contained in the article above, it cannot be carried out simultaneously when a husband and wife do not live together in the same house. The determination of child custody when a divorce occurs is carried out by a decision from the Court. The stipulation of child custody is not clearly explained in Law Number 1 of 1974 concerning Marriage.

In determining child custody for an adult child, the judge gives his own choice. Regarding adult children, Article 330 of the Civil Code (KUHPerdata) is also explained, which is 21 years old.

\section{Determination of Child Custody in terms of Psychology}

The family is the place where children grow and develop in facing the future. The importance of the role of both parents in maintaining family harmony to maintain the psychological stability of children. Divorced parents will greatly affect the development and psychology of a child. Parenting patterns will be different before the parent's divorce so that the basic needs of a child are not met (Wasil Sarbini, 2014).

Several factors influence a person's development, including:

1. Heredity, Environment, and Maturity

Some factors that influence the development of a child are hereditary. Hereditary is a characteristic mechanism from one generation to the next, for example, a parent's genes are passed on to their children. In addition, the environment is also very influential both from the inner environment and the outer environment (uterus), namely the world outside one's self-starting in the womb to learning that comes from experience.

2. Development Context 
Humans are social creatures. The family is the most important part of the influence of a larger change, including the neighborhood and society at large. There are two forms of family structure found, namely nuclear-family and extended-family. nuclear-family or commonly referred to as the nuclear family, a household consisting of one or two parents and their children. Extended-family or can be called a large family is a multigenerational relationship consisting of grandparents, uncles, aunts, cousins, and relatives who are more distantly related. If the parent's divorce, the child will live with one of the parents and there is even a possibility that it will include stepparents and stepbrothers. This incident will affect the development of the child.

3. Normative and Nonnormative Influence

Normative are biological events or related to the environment that affects the majority in society. In addition to normative influences, there are also non-normative influences. These influences are unusual events that have an impact on a person's life because they disrupt the normal sequence of the life cycle.

4. Effect of time: Sensitive or critical period

The critical period is the time when the appearance of an event or the absence of an event has a special influence on a person's development (Rini Hildayani, 2014).

Of the several developmental factors above, one of the most influencing factors is the family factor. Parents have a great impact on the growth of children from childhood to adulthood and then into adulthood, parents must provide a peaceful and conducive environment that helps them in their intellectual, social, emotional, psychological, and spiritual development (Mahmud, 2020).

Parents greatly influence the growth and development of children. If parents experience a divorce, the psychology of the child will be disrupted, especially regarding the determination of child custody. Psychology plays a role in determining child custody, the consideration is that children are more likely to have emotional closeness to their mother or father. Determination of child custody when viewed from the psychology of the focus on the comfort of the child. If when the determination of child custody is not appropriate, it is not by the comfort of the child, the child's psychology will be disturbed and there will even be pressure on his psyche.

\section{Determination of Child Custody in terms of Economics}

Determination of post-divorce child custody also involves who will bear the cost of the child's needs, such as covering access, preschool/school, or other child's needs (Ann-Sofie Bergman, 2017). All humans have needs, needs are goods or services needed by humans to support all activities in carrying out daily life. Human needs are grouped into 3 parts, namely: (Yuliawati, 2019).

1. Primary needs are the main needs or the most important needs to live life, such as food, drink, clothing, shelter, education, and health.

2. Secondary needs are needs as a compliment that is met after the fulfillment of primary needs. These needs such as entertainment needs, electronic equipment, and household furniture. 
3. Tertiary needs are needs as equipment for human life whose fulfillment does not have to be fulfilled. The need for luxury goods such as means of transportation, communication tools, and jewelry.

Some of the needs above must also be accepted by a child. It is the duty of both parents, especially a father, to meet these needs. After the divorce, the father's obligation to provide for the children's needs is not interrupted. Determinants of child custody can be considered with the economic stability of the husband or wife because economic finance greatly affects the fulfillment of children's needs. A child has the right to have his/her needs met, both primary, secondary, and tertiary needs, even though the parents are divorced. In this case, to make it easier to meet the needs of the child, it can be seen who is more established financially and economically to meet the needs of children, both husband, and wife. If the child's needs have been met properly, then the child's life in the future will be good.

\section{Discussion}

A marriage that ends in divorce is something that no one wants. One of the problems that arise is regarding the upbringing of children. In a study of the parenting styles of mothers and fathers in various custody settings, it was concluded that mothers in single custody and mothers in joint custody settings were more likely to be supportive and controlling (i.e., authoritative parenting styles), than mothers without physical custody more tend to be supportive (ie, permissive parenting). As for fathers, the results reveal that although most divorced fathers do not have sole physical custody, fathers tend to have authority. Non-resident fathers and fathers in joint custody arrangements are more likely to be permissive (Kim Bastaits, 2017). From this explanation, it is clear that parenting after divorce is more dominant to a mother who has a pattern in good parenting so that she can support and control the child, both in terms of the development and association of the child.

However, the determination of child custody using an interdisciplinary approach provides a very broad understanding. In determining child custody, a court judge does not only consider the age of the child but there are other considerations such as the child's psychology. Using various approaches from various fields can prevent negative impacts on children, for example, child neglect. If one negative impact occurs, it will cause other negative impacts that will occur, such as juvenile delinquency, which is not only detrimental to oneself but can harm others.

The rapid development of the times, especially in the field of technology, makes parents have to be more vigilant in supervising the behavior of children. That way, divorced parents must prioritize the interests of the child and provide good care for the child. Therefore, in granting the determination of child custody, more attention must be paid to both from a psychological and economic point of view. In addition to prioritizing financially to meet children's needs, a psychological approach is also needed 
to avoid the occurrence of slow development in children and children's bad attitudes.

Physical parenting can also be done together and has a good impact on the relationship between parents and children. From the results of research conducted by Kim Bastaits and Inge Pasteels, it is concluded that joint physical custody compared to single custody (mother and father) has a better impact on post-divorce parent and child relationships in terms of open communication and support(Kim Bastaits I. P., 2019). From some of the considerations that have been explained that the determination of child custody must prioritize the interests of the child without having to prioritize the ego of the husband or wife.

\section{Conclusion}

Based on the discussion above, it can be concluded that an interdisciplinary approach is an approach to solving a problem by using a review from various perspectives of cognate and relevant sciences that can solve problems. Custody of children (hadanah) is one of the problems that can be solved by using an interdisciplinary approach that is viewed from several fields of science.

In this paper, the author uses Islamic law, marriage law, psychology, and economics. After reviewing that the determination of child custody due to divorce does not only focus on the age of the child but other considerations affect the determination of child custody. The determination of child custody for children who are not yet mature or who are not yet mumayiz is more dominantly given to the mother because the child still needs the love of a mother figure.

The suggestion from the author is that from the results of this study the author hopes for further research on issues regarding the determination of child custody that occur in the community. 


\section{References}

Najjeh, Abu Ahmad, (2017). Fikih Mahzab Syafici, Bandung: Marja.

Sarong, Hamid, (2010). Hukum Perkawinan Islam Di Indonesia, Banda Aceh: Yayasan PeNA.

Tarjo, (2019). Metode Penelitian, Yogjakarta: Deepublish.

Alfiah, Mukti Arto dan Ermanita, (2018).Urgensi Dwangsom Dalam Eksekusi Hadanah. Jakarta: Kencana.

Sari, Milya dan Asmendri,(2020)."Penelitian Perpustakaan (Library Research) Dalam Penelitian IPA.” Jurnal: Science. 6(1), 41-43.

Yuliani dan Wiwin, (2018). "Metode Penelitian Deskriptif Kualitatif Dalam Perspektif Bimbingan dan Konseling." Jurnal: Quanta. 2(2), 8391. https://doi.org/10.22460/q.v2i2p83-91.1641

Sudikan, Setya Yuwana, (2015). "Pendekatan Interdisipliner, Multidisipliner dan Transdisipiner Dalam Studi Sastra." Pramasastra: Jurnal Ilmiah Bahasa Sastra dan Pembelajarannya. 2(1), 1-30. https://doi.org/10.26740/parama.v2n1.p\%25p

Ni'mawati, (2020). "Kajian Riset Monodisipliner dan Interdisipliner Dalam Pendidikan Islam Menghadapi Isu Nasional dan Global: Studi Kasus Terhadap Isu Covid-19." Jurnal:Misykat. 5(1), 101122.http://dx.doi.org/10.33511/misykat.v5n1.101-122

Rohmatika,Ratu Vina, (2019). "Pendekatan Interdisipliner dan Multidisipliner Dalam Studi Islam", Jurnal: Al-Adyan. 14(1) 118.https://doi.org/10.24042/ajsla.v14i1.4681

Muhajirin, Achmad, (2017) “Hadanah Dalam Islam.” Jurnal SAP. 2(2), 1-9. http://dx.doi.org/10.30998/sap.v2i2.2089

Hifni, Mohammad, (2016). "Hak Asuh Anak Pasca Perceraian Suami Istri Dalam Perspektif Hukum Islam.” Jurnal: Hukum Keluarga. 1(2), 1-32. http://dx.doi.org/10.32678/bildalil.v1i02.123

Sunarto, Muhammad Zainiddin \& Ahmad Baidawi, (2020). "Hak Asuh Anak Dalam Perspektif KHI Dan Mahzab Syafi'i’, Jurnal HAKAM, Vol. 4 No. 1, 1-20. http://doi.org/

Sarbini, Wasil dan Kusuma Wulandari. (2014). "Kondisi Psikologi Anak Dari Keluarga Yang Bercerai (The Conditions Of Child Psychology Toward Family Divorced)."

Rini Hildayani, Muhammad Sugianto, Retno Tarigan, Eko Handayani. (2014). "Perkembangan Manusia." Jurnal: Psikologi Perkembangan Anak.

Yuliawati, Nitami dan Gigih Pratomo (2019) "Analisis Penngaruh Kebutuhan Ekonomi Keluarga Terhadap Pendapatan Tenaga Kerja Wanita (Studi Kasus di Industri Kulit Kota Surabaya)", Jurnal: Emonomie 1(1), 1-18.

Samad, Muhammad Yunus, "Hukum Pernikahan Dalam Islam", Jurnal: Istiqra', vol. 5, no. 1 (2017):

Putri, Nesi Rahayu dkk., (2019). "Faktor Penyebab Masalah Keluarga Dewasa Awal Di Kampung Muara Pandan Kecamatan Ranah Pesisir Kabupaten Pesisir Selatan", Skripsi, Purwakarta, Institut Agama Islam Negeri Purwakarta.http://repo.stkip-pgrisumbar.ac.id/id/eprint/7846 
Bergman, Ann-Sofie, Annika Rejmer. (2017) "Parents In Child Custody Disputes: Why Are They Disputing?', Journal Of Child Custody, vol. 14, 1-18. https://doi.org/10.1080/15379418.2017.1365320

Bastaits, Kim, Inge Pasteels. (2019) "Is Joint Physical Custody In The Best Interests Of The Child? Parent-Child Relationships and Costodial Arrangements', Journal Of Social and Personal Relatoinshoips. 20(5), 1-21. https://doi.org/10.1177/0265407519838071

Bastaits, Kim, Dimitri Mortelmans. (2017) "Parenting And Family structure After Divorce: Are They Related?', Journal Of Divorce \& Remarriage, Vol. 58, 1-18. https://doi.org/10.1080/10502556.2017.1345200

Razak, Mohd Abbas Abdul, Mek Wok Mahmud, (2020) "The Role Of Costum In Magaging Child Custody: A Juridico- Psychological Analysis In Local Context'. Journal Of Islam In Asia. 17(3), 1-18. https://doi.org/10.31436/jia.v17i3.989 